\title{
Idiopathic Acquired True Leukonychia Totalis and Partialis
}

\author{
Seo Wan Kim, Mi Sun Kim, Tae Young Han, June Hyunkyung Lee, Sook-Ja Son
}

Department of Dermatology, Eulji General Hospital, Eulji University, Seoul, Korea

\section{Dear Editor:}

A 19-year-old male patient presented with one-month history of progressive whitening of his toenails. The nail change began with central white spots on the toenails that progressed over one month to almost total nail whitening. The growth of the nails was otherwise normal. He was healthy and without a previous medical history. He had not experienced any exposure to medications, chemicals, or mechanical trauma to the nails. There was no family history of leukonychia or other dermatologic diseases.

On physical examination, partial to total leukonychia of all toenails was observed. The right great toenail exhibited a totally chalky white discoloration. However, the distal portion of the other toenails had a pink transverse band about 2 or $3 \mathrm{~mm}$ wide at the free edge (Fig. 1). The surface of the nail did not demonstrable further change, such as pitting, ridging, or subungual hyperkeratosis. Otherwise, all fingernails were normal and the patient had no other organ abnormalities.

The results of the laboratory studies, including complete blood count, blood chemistry profile, and urinalysis, were all within normal limits. Repeated potassium hydroxide preparations and fungal cultures of the toenails were negative.

Punch biopsy was performed at the proximal nail fold of his left great toenail. Histopathologic examination of the

Received Setember 21, 2012, Revised February 21, 2013, Accepted for publication April 22, 2013

Corresponding author: Sook-Ja Son, Department of Dermatology, Eulji General Hospital, 68 Hangeulbiseong-ro, Nowon-gu, Seoul 139-711, Korea. Tel: 82-2-970-8580, Fax: 82-2-974-1577, E-mail: ssjmdderma@ daum.net

This is an Open Access article distributed under the terms of the Creative Commons Attribution Non-Commercial License (http:// creativecommons.org/licenses/by-nc/3.0) which permits unrestricted non-commercial use, distribution, and reproduction in any medium, provided the original work is properly cited. nail plate revealed sparse parakeratosis with globular collection of keratohyaline granules (Fig. 2). A biopsy specimen from the nail bed and nail matrix were unremarkable. During the 6-month follow-up period, the discoloration of the toenails did not significantly change. Leukonychia is the most common chromatic abnormality of the nail. True leukonychia is an abnormality of the nail plate that originates in the matrix ${ }^{1}$. The mechanism of leukonychia is not clear. The nail plate normally consists of cornified cells that contain keratin. However in leukonychia, as a result of abnormal matrix keratinization, persistent parakeratosis, keratohyaline granules, and dissociation of keratin bundles are present. Disorganization of the keratin fibrils leads to the diffraction of visible light in
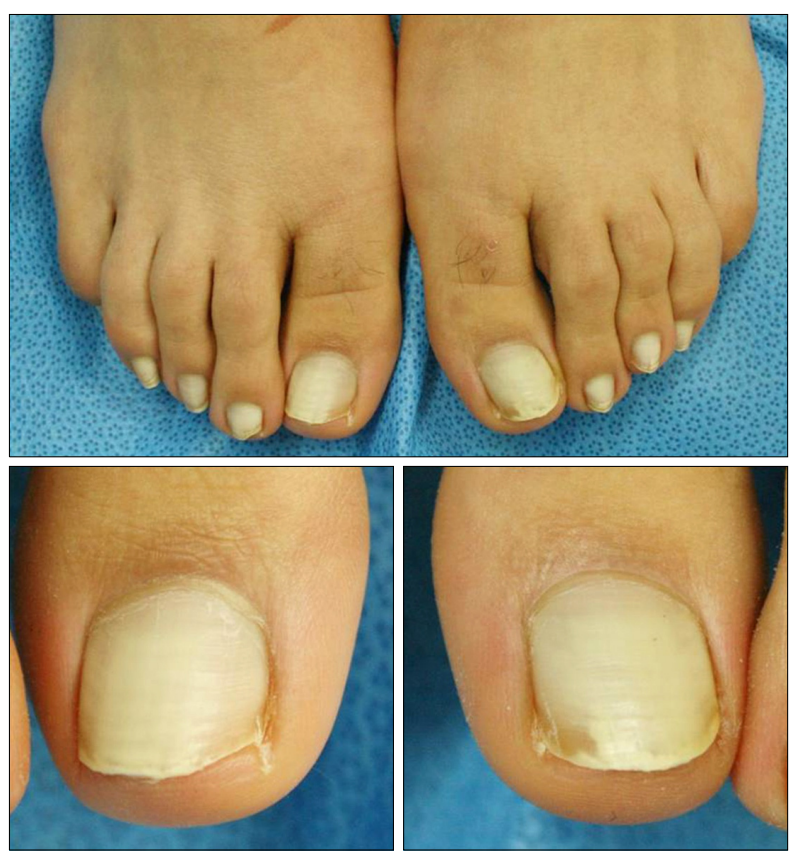

Fig. 1. All toenails showed chalky white and opaque nail plates characteristic of leukonychia. 

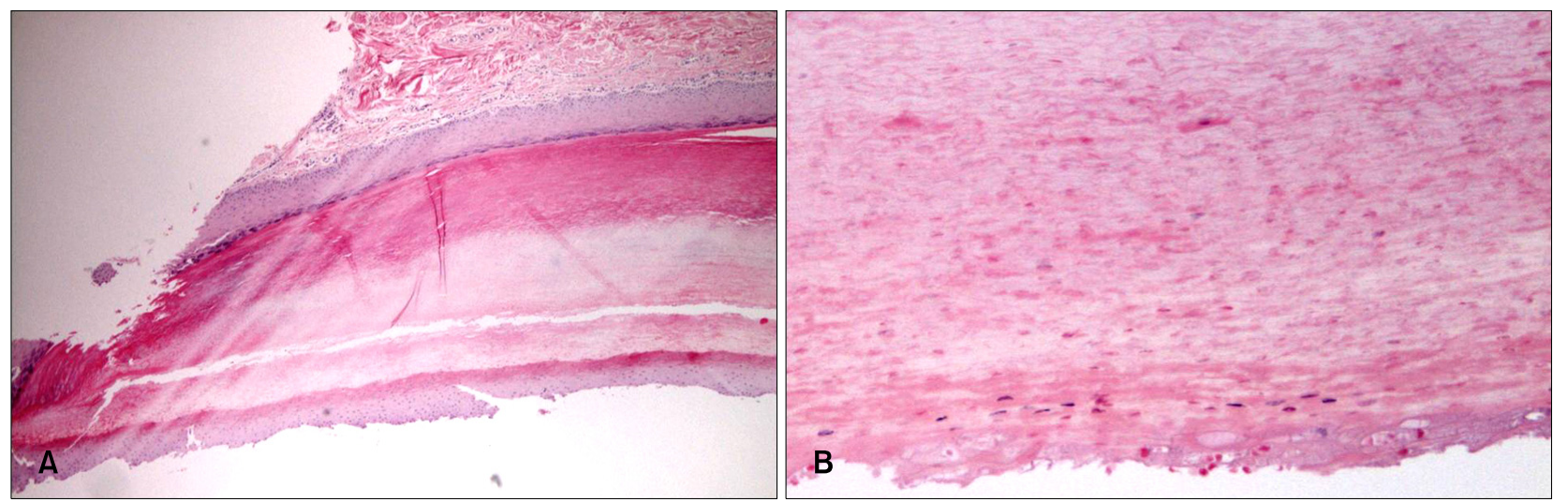

Fig. 2. Histopathology of the nail plate showed sparse parakeratosis with globular collection of keratohyaline granules keratohyaline granules (H\&E; A: $\times 40$, B: $\times 200)$.

the parakeratotic cells, resulting in a white nail, which prevents visualization of the underlying pink vascular bed $^{2-5}$.

True leukonychia may be inherited or acquired. Inherited leukonychia can be an isolated condition or one of several inherited leukonychia syndromes ${ }^{2}$. If true leukonychia is acquired, it may be associated with trauma, chemotherapeutic agents, hypocalcemia, zinc deficiency, heavy metal poisoning, local infection, and systemic disea$\operatorname{ses}^{1,2,4,5}$.

Idiopathic acquired true leukonychia is a rare condition, with only six reported cases in the literature ${ }^{1-5}$. All of those cases as well as our case showed progression from leukonychia partialis to combined leukonychia totalis and partialis. All of previous reported cases involved the fingernails, and among these, four cases appeared at the fingernails and toenails. Our case is different from those reported cases; because of our case involved only the toenails without involvement of the fingernails.

In conclusion, true leukonychia can occur associated with trauma, drugs, infection, or systemic diseases. We thought that one of these must be the cause of development of true leukonychia, but we could not find any trauma history, systemic problem, or onychomycosis in our cases. Based on previous reports, we suggest that leukonychia might develop without underlying causes in some patients. This was a rare case with asymptomatic progressive idiopathic acquired true leukonychia totalis and partialis of the toenails without a hereditary cause.

\section{REFERENCES}

1. Park HJ, Lee CN, Kim JE, Jeong E, Lee JY, Cho BK. A case of idiopathic leuconychia totalis and partialis. $\mathrm{Br} J$ Dermatol 2005;152:401-402.

2. Bongiorno MR, Aricò M. Idiopathic acquired leukonychia in a 34-year-old patient. Case Rep Med 2009;2009:495809.

3. Claudel CD, Zic JA, Boyd AS. Idiopathic leukonychia totalis and partialis in a 12-year-old patient. J Am Acad Dermatol 2001;44 2 Suppl:379-380.

4. Arsiwala SZ. Idiopathic acquired persistent true partial to total leukonychia. Indian J Dermatol Venereol Leprol 2012; 78:107-108.

5. Stewart L, Young E, Lim HW. Idiopathic leukonychia totalis and partialis. J Am Acad Dermatol 1985;13:157-158. 